\title{
Context and Priorities for Paediatric Research in the Eighties
}

\author{
S. D. M. COURT, ${ }^{(14)}$ EMERITUS PROFESSOR OF CHILD HEALTH \\ University of Newcastle upon Tyne, England
}

\section{INTRODUCTION}

The discipline within which this review is made is epidemiology: the study of the group to complement the study of the individual. The intention is to show how an academic department of Child Health has used this method to study the health needs of children, to consider aspects of paediatrics to which it might be applied in the next decade, and to see how experience and prediction relate to each other.

I accept William Harvey's definition of "research" given three centuries ago: "To search out and study the secrets of Nature by experiment." The words "context" and "priorities" in the title are more difficult, and I seem to reach their meaning through a common English saying which has applied to me more often than I like to remember. "He can't see the wood for the trees."

The saying is a recurring experience in forestry, where an uncontrolled landscape reveals a confusion of trees and woods and where selective felling and planting create a clarity of wood and trees.

The wood is context, the trees priorities, and my thesis is that relevant priorities are only found if we understand the context from which they arise and in which they must be sought.

I shall not refer to technical advances, necessary as they are, because I am concerned not with techniques but with the ideas that direct them. Of course, I accept the drive of the individual question in research and the personal commitment which must pursue it to the end.

However, unrestrained individualism has led to the suffocating impact of the publication explosion which overwhelms us when we survey the range of journals in any scientific library. From this position, the question takes a different form and asks, "Can the dynamic of individual enquiry live in constructive tension with the restraints of the context within which it must work?"

\section{CONTEXT}

The content of the context, of necessity personal, selective, and incomplete, is shown in Table 1 . The commentary which follows is selective, too, but stresses the key components with their changing character and changing relationships.

\section{CHILDREN}

Children are the reason for our discipline, and the question they ask is: "Is the improvement of our health and development always at the center of your research?"

\section{CHANGING FAMILIES}

Most children live in families, and the family is still a relatively stable feature of Western society although we can no longer use the term as if it had a single, accepted meaning. Many parents care effectively or adequately for their children, but a significant number do not.

Twenty-five years ago, the position in Newcastle was measured by a continuing family survey, and the broad distribution of family care is shown in Table 2 . The criteria for measurement are defined in the second account of the Family Study $(3,4,11)$. The "adverse factors" in Table 2 were loss of parental care ("deprivation"), failure to provide adequate food, clothing and sleeping accommodation ("deficiency"), and persistent breakdown ("dependence").

In contrast to some European neighbors, in Britain, social disadvantage is widening. A million and a half children are living in one-parent families, 120,000 are in public care, and divorce continues to rise at an alarming rate (Fig 1).

\section{CHANGING PATTERN OF DISEASE}

The health problems of children in the developed world today are shown in Table 3. The labels are the same; the order has changed. No longer is acute episodic illness the centre of our concern; it is being overtaken by chronic disease, physical and mental handicap, psychiatric disorders, and ill health arising from social disadvantage, family dysfunction, and breakdown. We need to turn Table 3 upside down to see the disease context of our inquiries in the next decade.

This changing pattern of disease calls for a new type of relationship between doctors, children, and parents, not only the intermittent contact leading to the traditional response of diagnosis, treatment, recovery, and withdrawal, but a continuing relationship with joint decision-making and true partnership. The relevance of this to studies involving families is obvious; without such a relationship, the full store of parental information will not be forthcoming.

\section{THE RELEVANT COMMUNITY}

The relevant community for each inquiry must be found and known from the inside. From 1973 to 1976, I was involved in a survey of the health services for children in England and Wales (1). This country-wide view had its uses; the danger was that it tended to see general problems with general answers. Previous experience should have alerted me to this danger and to the need to identify the range of communities within the national community with their differing needs and facilities.

I can best illustrate this range as it has affected the research of the University Department of Child Health and related departments in Newcastle in the past 40 years.

The relevant communities are the Northern Region of England (population, 3.5 million), the city of Newcastle upon Tyne (population, 250,000), "localities" within the city with known but varying populations.

An outline map of the last with the distribution of early child mortality and child abuse is shown in Figure 2.

Having selected from this certain disadvantaged communities along the river, the University Department of Child Health in partnership with the parents, general practitioners, nurses, social workers, and teachers who work there, is examining needs and services through direct involvement in health care (7). Table 4 illustrates how the University Departments of Child Health, Ob- 
CONTEXT OF RESEARCH

Children

Changing families

Changing pattern of disease

Changing professional relationships

The relevant community

Commitment to prevention

Scientific method

Finance and facilities

\section{THE QUALITY OF FAMILY LIFE IN 847 FAMILIES}

Categories of Family Life
Families without
adverse factors
Families with one or two
adverse factors

No. $\%$

$379 \quad 45$

$397 \quad 47$

Families with all three factors

71

8

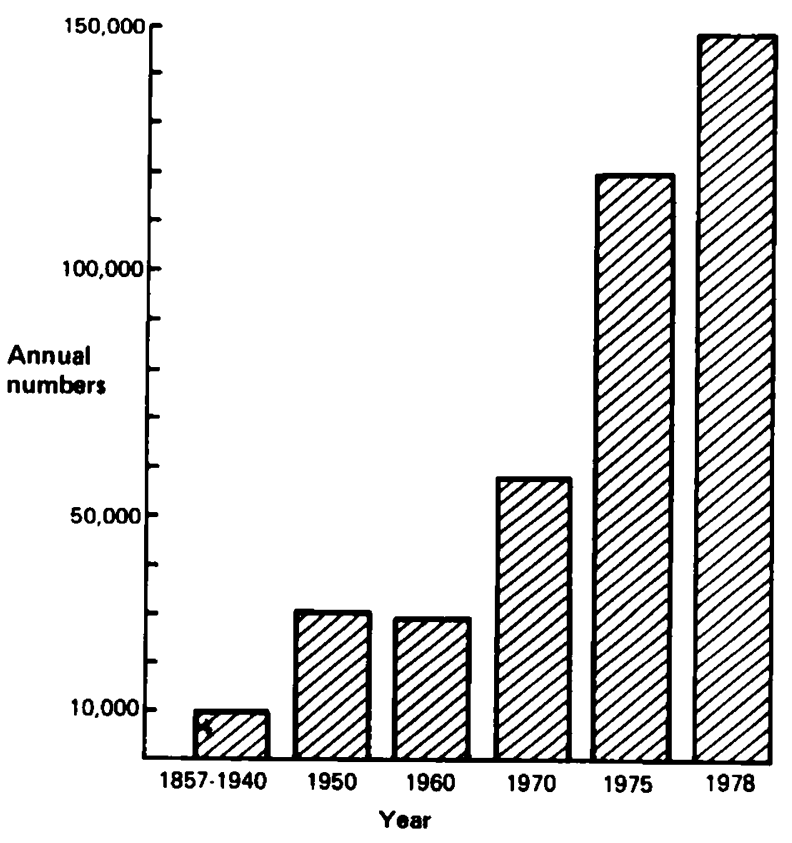

Fig. 1. Divorce in England and Wales 1857-1978.

stetrics, Child Psychiatry, and Family and Community Medicine have explored their communities over the last $\mathbf{4 0}$ years.

\section{COMMITMENT TO PREVENTION}

In recent years, the British Department of Health and Social Security has been singing the praises of prevention, yet has done virtually nothing to promote it. Governments will the ends but fail to will the means. Prevention is an attitude before it is an activity. I believe governments will not respond until paediatricians show a profound shift in their thinking and practice towards "prevention" and discover, problem by problem, how it can be done.

\section{LOYALTY TO THE SCIENTIFIC METHOD}

It may surprise many to see loyalty to the scientific method as an essential part of the context.

We take it for granted, but unhappily what is called "alternative medicine" is gaining ground. Although always open to new ideas from whatever quarter they come, we must ask for established methods of validation to be accepted by both sides.

\section{FINANCE AND FACILITIES}

In 1977, the Expenditure Committee of the British Parliament published some revealing facts (6). Accepting the difficulty of sharp distinctions between therapeutic and preventive action, they estimated that in the previous year, the National Health Service had spent $£ 5000$ million on treatment, $£ 88$ million on prevention, and $\mathbf{f} 0.5$ million on research. British governments have never been eager to support research, and at a time of financial retrenchment like the present, severe reductions in grants to Universities and to individuals are taking place.

In a difficult economic future, we shall have to work harder than ever for funds and facilities for research.

\section{CHILDREN'S HEALTH PROBLEMS IN ENGLAND AND WALES NOW}

Defective Fetal Growth
Hazards of Birth
Bodily malformation
Illness
Injury
Physical or Mental handicap
Psychiatric disorders
Educational failure
Social handicap
Parental deficiency

DISTRIBUTION OF EARLY CHILD DEATHS AND CHILD ABUSE IN NEWCASTLE UPON TYNE 1976-76

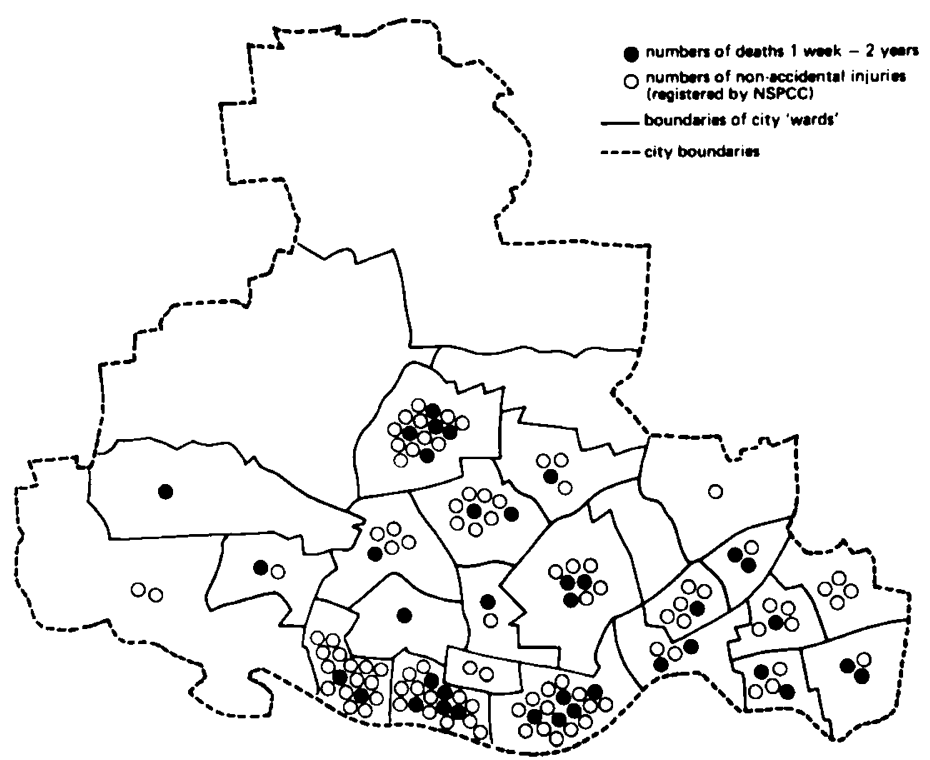

Fig. 2. Outline map of Newcastle upon Tyne with distribution of early child mortality and child abuse. 
COMMUNITY STUDIES :

NEWCASTLE CITY AND REGION : $1939-1980$

$\begin{array}{ll}1939 & \text { Newcastle: Causes of all infant deaths } \\ 1947-1962 & \text { Newcastle Thousand Family Survey } \\ 1951-1975 & \text { Region: Study of Haemolytic Disease of Newborn } \\ 1960-1962 & \text { Newcastle Maternity Survey } \\ 1960-1973 & \text { Newcastle Study of Child Development } \\ 1969- & \text { Region: Study of Children's Cancer } \\ 1970- & \text { Newcastle: Operational Research into Maladjustment } \\ 1979- & \text { Thousand Families Revisited } \\ 1979- & \text { Newcastle: Riverside Project } \\ 1980 & \text { Region: Study of Paediatric Care in Y8 Training } \\ & \text { Getletal Practices }\end{array}$

In summary, the context for paediatric research in the next decade will include the old and the new, the established, and the changing.

The content will be children, changing families, a changing pattern of disease, changing professional relationships, finding the relevant community and knowing it, commitment to prevention, holding firm to the scientific method, and sustained pressure for funds and facilities.

\section{PRIORITIES}

If that is the wood, what are the trees? What priorities stand out in such a context? At this point, the late Professor Jack Tizard would have repeated his general conviction: "No research without proposals" (1). My selection which lead to my proposals is given in Table 5 , followed by comments which examine the reasons for the choice and the relationships between priorities and context.

\section{CONTROL OF BIRTH WEIGHT}

If the central aim of paediatric research is to improve the health and development of children, the first priority will be fetal and perinatal health (Table 6, Ref. 13). At the heart of this are the control of birth weight and of preterm delivery.

Newcastle's main contribution has been the Maternity and Child Development studies from 1960 to 1973, and I suspect that, in view of G. A. Neligan's untimely death, many are not familiar with the collected data from those studies $(5,8)$. The adverse effects on survival, growth, and educational performance associated with low birth weight are known, and in Britain, the proportion of children with birth weights below $2501 \mathrm{~g}$ has not declined in 30 years. Is this, as Neligan suggests, because we have almost exclusively followed the clinical road, when the main highway is social and educational? In Britain, too, it would seem that behind the stops and starts of reproductive research in this period there has been a loosening of the partnership between obstetricians, paediatricians, and perinatal physiologists which began so promisingly 30 years ago. We give so much more attention to the "how" of low birth weight than to the "why." Yet, if the major influences on birth weight and fetal health are "social," it would be rational to make professional and political pressure for social and educational improvements, especially for the socially disadvantaged, the main priority. The evidence supports this, but there is a second road which leads through the antenatal clinic, delivery room, special care, and intensive care nursery. The infants who travel the final stretch of this road may be few in relation to the country's total births, but the quality of their care can profoundly affect survival and development.

For the majority of births, a great deal of information still waits collection. What has been the training of the doctors and nurses who provide the care? What are the numbers and distribution of skilled staff over the $24 \mathrm{hr}$ ? How do mothers use the services we provide? How do we measure and manage maternal stress in pregnancy? How systematically do we look for maternal infection? What degree of agreement and consistency is there in the management of early preterm labor? What is the quality of preconceptional and antenatal education on child-mother relationships, especially in relation to childbearing, feeding, smoking, alcohol, and "medicines" for the pregnant woman? Why don't mothers do what doctors tell them?

I am not claiming that attention to these and to other aspects would produce specific improvements, but quantitative investigations followed by planned experiments provide the only reasonable hope of finding out.

\section{CHILD AND FAMILY "PERFORMANCE"}

The family studies in Newcastle brought back to our thinking the concept of performance. This meant that instead of focusing immediately on defined disorders, a broad look was taken at hindrances to the development of "physical performance," "social performance," "educational performance," over the whole range, and not just at the $1 \%$ lower limit we tend to label "disease." This complex area of child and family need involves a spectrum of related and overlapping processes-low economic status, low birth weight, birth damage, intellectual limitation, learning difficulties, poverty of parenthood, child neglect, and injury. Their extent, even in an advantaged community, is shown in Table 7.

Looking at the collective prevalence, excluding social handicap and allowing for overlap in 1964 to 1965, one in six children between 9 and 11 years in a privileged community had a chronic handicap of moderate or severe degree (9). In a parallel study by the same team in a disadvantaged area of London, the figure was one in four. These defects of performance affect a large proportion of the child population so that even nondramatic improvements could be important in their decline.

There are two main research implications. Neither incidence nor prevalence rates are sufficient for the planning of services.

\section{SELECTIVE PRIORITIES IN PAEDIATRIC RESEARCH}

Control of birthweight and pre-term birth
Child and family 'performance'
Prevention of serious accidents
Respiratory illness
Scientific study of services
Research with and for the developing world

LOW BIRTH WEIGHT AND PERINATAL MORTALITY IN 3 REGIONS OF ENGLAND AND WALES (1971)

\begin{tabular}{|c|c|c|c|}
\hline \multirow{2}{*}{$\begin{array}{l}\text { BIRTH } \\
\text { WEIGHT }\end{array}$} & \multicolumn{3}{|c|}{ P.N.M.R. } \\
\hline & $\begin{array}{l}\text { Advantaged } \\
\text { Rural }\end{array}$ & $\begin{array}{c}\text { Mixed } \\
\text { Industrial }\end{array}$ & $\begin{array}{l}\text { Disadvantaged } \\
\text { Industrial }\end{array}$ \\
\hline Over $2500 \mathrm{~g}$ only & 8.2 & 8.0 & 10.7 \\
\hline $\begin{array}{l}2500 \mathrm{~g} \text { or less } \\
\text { only }\end{array}$ & 6.8 & 13.7 & 16.3 \\
\hline $\begin{array}{l}\% \text { weighing } \\
2500 \text { or less }\end{array}$ & 3.7 & 6.2 & 7.7 \\
\hline
\end{tabular}


PREVALENCE OF HANDICAP IN A PRIVILEGED COMMUNITY 1964-65

Condition

Physical handicap

\% Handicap

Intellectual retardation

Educational backwardness

Psychiatric disorder

Each community must know the actual number of handicapped children and the types of handicap for which provision must be made.

Yet, the only real answer to handicap is not to have it. Many, perhaps the majority, of these disorders are potentially preventable so how should we proceed? We must reconsider our preventive responsibilities during pregnancy and birth. The incidence of cerebral palsy is falling in Sweden. We believe this is happening in Britain, too, and we are measuring it in the Northern region. We need to go deeper than this and assess the long-term effects of effective and deficient mother-child relationships. We need to identify "key events" which lead later to psychiatric disorders, now the widest band in the spectrum of defective performance. We need studies of marriage and parenting, family dysfunction, and divorce to identify the factors making for stability and for breakdown (12).

Such studies can only be done in the community and will need sensitive parent-professional relationships.

\section{THE PREVENTION OF SERIOUS ACCIDENTS}

The facts of Figure 3 are a notable achievement. In 1954, Sweden established a Joint Committee for Childhood Accident Prevention. In 1972, the Council of Europe asked member states to follow Sweden's example. Britain, through the persistence of one man, followed last year, and there the process has stopped (2). Committees don't conduct research, but they can create the public interest which facilitates inquiry and makes prevention acceptable. A disorder which is the main cause of death in childhood after the first year and the source of uncounted damage, distress, and expense should be a higher research priority than it is at present. The way forward, in the context of ongoing national or regional scrutiny, is the study in depth of specific types of accident followed by testing out models of prevention. The fall in the admission of children for salicylate poisoning in two cities with the introduction of child-resistant containers is one example of this (Fig. 4).

\section{RESPIRATORY ILLNESS}

Respiratory illness was selected because of the frequency and distress as well as the danger. We have all watched in our own children, and in child patients, the depressing succession of colds, sore throats, earache, coughs, wheezing, disturbed sleep, and day weariness in recurrent respiratory illness and can appreciate the despair which parents feel. "Can't something be done" is their constant plea, and what can be said in reply?

The infective element is mainly viral and the principal viruses are known. Recurrence is in part due to the variety of their types and strains, but host response is equally important and current studies show that children with many infections have a delayed and less effective production of specific secretary immunoglobulins than those with few.

Yet this does not open the way to general prevention. The first necessity for this is a knowledge of the distribution and behavior of respiratory viruses at all ages in the community; until that is available, we shall not know where preventive measures should be applied. What preventive measures are available? Few, but more than 10 years ago. It is disappointing that in spite of sustained inquiry a safe and effective vaccine against respiratory syncytial virus for the young infant still eludes us. However, although formidable problems of production and testing remain, the effective large scale production of Interferon may be nearer than we thought (10). Another promising approach will be not only the promotion of breast-feeding but in studying the nature of its protective immunology.

Asthma, the other major component of recurrent respiratory

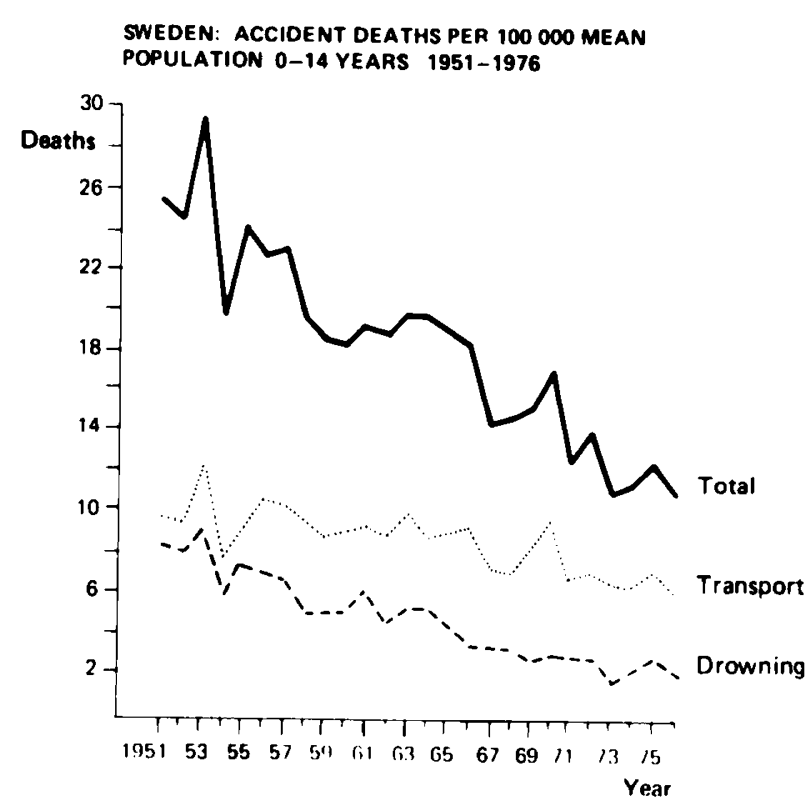

Fig. 3. Improving pattern of childhood accidents in Sweden.

FALL IN CHILD ADMISSIONS FOR SALICYLATE POISONING IN CARDIFF ANO NEWCASTLE WITH THE INTRODUCTION OF CHILD-RESISTANT CONTAINERS

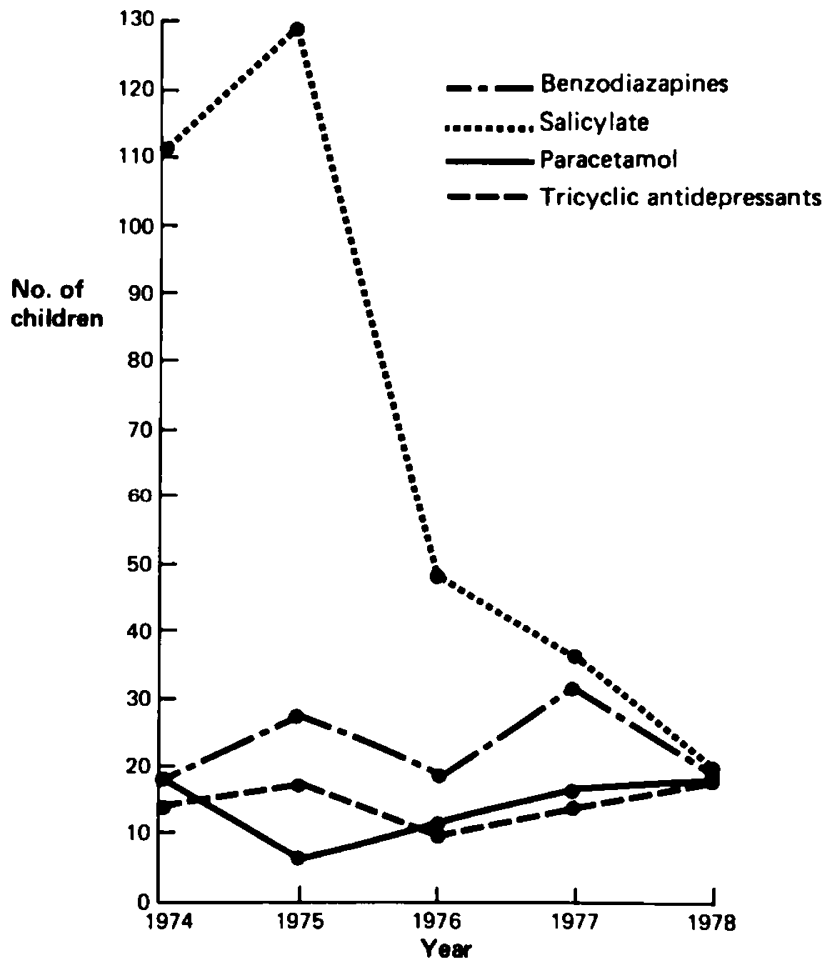

Fig. 4. Fall in salicylate poisoning with the introduction of child-resistant containers in Newcastle and Cardiff. 
illness, is not considered here. Although management has notably improved, current drugs suppress rather than prevent the basic reaction. In this sense, we are still at an early stage in the search for prevention, which calls for a closer partnership between immunology and paediatrics than has been customary so far.

\section{THE SCIENTIFIC STUDY OF SERVICES}

The end of research is application, and so it must include the study of services. My experience from 1973 to 1976 in the assessment of the child health services in England and Wales (1) convinced me that planning would never be rational until services were brought within the framework of scientific inquiry. We need a new style of policy making in which decisions are made, after the facts are found, after controlled trials, and after the use of costed models and local experiments. Equity of distribution in services and efficiency in their administration count for nothing unless they are associated with a consistent and rising quality of care. The measurement of quality in every discipline should be among our highest priorities, but the methodology is not well worked out and still requires critical study.

\section{RESEARCH WITH AND FOR DEVELOPING COUNTRIES}

The last priority is our research responsibility for developing countries. Their main problems-excess population, malnutrition, infective and parasitic disease - and the techniques for their control, are known. Research, therefore, will be concerned with discovering ways for the effective and inexpensive delivery of appropriate care. Although this remains the first objective, it would be unwise to be content with that. The search for a malaria vaccine, although making progress, still requires continuing fundamental research. Now that $M$. leprae can be grown in the laboratory, a vaccine against leprosy is possible but not achieved. The elimination of these two diseases alone would produce a notable increase in health in the Third World. Departments of Nutrition and Tropical Child Health must still explore the complex interface between malnutrition and infective illness.

More subtle issues, for example, the relation between maternal nutrition, prolonged breast feeding and family spacing, are no less important. Is the high prolactin level and the associated amenorrhea dependent on maternal nutrition or on the prolongation of breast feeding itself? If the latter, maternal nutrition can be improved without substantially diminishing the birth interval. The development of new insights leading to the retention or change of cultural practices is essential for population control and for increasing maternal and child health.

Nowhere is the need for research to decide the priorities of health care more necessary than in the worlds developing communities.

\section{REFLECTION ON WHAT HAS BEEN LEFT OUT}

There will be surprise that the priorities did not include malformations, cancer, or the metabolic and system disease which call for continuing and fundamental study. The first reason is the need for a quantitative approach to the problems facing paediatrics and for an examination of the prospects for advances in prevention in the next decade. There are a number of measures besides amni- ocentesis which would diminish the number of malformed children who are born, but little promise of prevention (as distinct from abortion) of single gene or chromosomal defects in the time under review. In cancer, the collaborative testing of planned treatment regimes, especially in lymphoblastic leukemia, Hodgkins reticulosis, and nephroblastoma, are proving effective to the point where the word "cure" can be used. The end of that therapeutic road has not been reached, but etiological understanding proceeds more slowly, and prevention is not in sight. The second reason for the asymmetry of presentation is related to the social objectives of this paper.

Others would have given a different list of priorities, and there is no suggestion that the selection here has greater authority than any other. Its claim to attention is that it is derived from the changing extent and pattern of children's health needs, the possibilities for preventive progress in the next decade, and the convictions and bias of a university department's professional experience.

We live in the same wood and should cherish each others trees.

\section{CONCLUSION}

The central aim of paediatric research is to improve the health and development of children.

The hope of this paper is that by illustrating some applications of pediatric epidemiology it would extend the unfinished bridge between "cellular" and social pediatrics.

Its main conclusion is the necessity in all research of defining the context and deriving priorities from it.

As the fulfillment of research is in its application, the scientific study of the services which can make this possible is an essential link between review and reform.

\section{REFERENCES AND NOTES}

1. Court, S. D. M.: Fit for the Future: Report of the Committee on Child Health Services, Chairman., Vols. 1 and 2 (H. M. S. O., London, 1976).

2. Jackson, R. H.: Children, the Environment and Accidents. (Pitman Medical, London, 1977).

3. Miller, F. J. W., Cour, S. D. M., Knox, E. G., and Brandon, S.: The School Years in Newcastle upon Tyne. (Oxford University Press, London. 1974).

4. Miller. F. J. W., Court, S. D. M.. Walton. W. S., and Knox, E. G.: Growing up in Newcastle upon Tyne. (Oxford University Press, London, 1960).

5. Neligan, G. A., Prudham, D., and Steiner, H.: The Formative Years. (Oxford University Press, London, 1974).

6. Report of the House of Commons Committee on Expenditure. (H. M. S. O., London, 1977).

7. The Riverside Project. M. A. P. S. Downhan, Department of Child Health, University of Newcastle upon Tyne (1979).

8. Russell. J. K., Fairweather, D. V. T., Millar, D. G., Brown. A. M., Pearson, R. C. M.. Neligan, G. A., and Anderson, G. S.: Maternity in Newcastle upon Tyne. Lancet. I: 711 (1963).

9. Rutter, M., Tizard, J., and Whitmore, K.: Education, Health and Behavior. (Longman. London, 1970).

10. Scott, G. M., and Tyrrell, D. A. J.: Interferon: Therapeutic Fact or Fiction for the 80's. Br. Med. J., I: 1558 (1980).

11. Spence, J. C., Walton, W. S., Miller, F. J. W., and Court, S. D. M.: A Thousand Families in Newcastle upon Tyne. (Oxford University Press, London, 1954).

12. Thomas, B., and Collard, J.: Who Divorces? (Routledge \& Kegan Paul, London, 1979).

13. Wynn, M., and Wynn, A.: The Prevention of Preterm Birth. (Foundation for Education \& Research in Childbearing. London, 1977).

14. Requests for reprints should be addressed to: Dr. S. D. M. Court, 8 Towers Avenue. Jesmond. Newcastle upon Tyne 2, NE2 30E, England. 